\title{
Problems Faced by Agricultural Landless Laborers in Cuddalore District, Tamil Nadu: A Status Analysis
}

\author{
A. Janifar ${ }^{1}$ and S. Chandrasekaran ${ }^{2}$ \\ ${ }^{1}$ Research Scholar, ${ }^{2}$ Assistant Professor, \\ ${ }^{1 \& 2}$ Centre for Rural Development, Annamalai University, Chidambaram, Tamil Nadu, India \\ E-Mail: janifarphd92@gmail.com
}

\begin{abstract}
India is the second the largest part populous country of the world and has changing socio-economic condition and political demographic and morbidity patterns that have been illustration global thought in current years. Though in recent times enacted MGNREGA, 2005 provides 100 days guarantee of employment in a year, there is great deal of fraud in issuing job cards. Moreover, gather rolls are not maintained accurately and work is not provided to job seekers who really are in need of such support. The problem of agricultural landless laborers is part of the wider problem of unemployment and under-employment in rural areas. Research is primarily a study of how the problems of agricultural workers face. The study is conducted among the farmers in the Parangipettai block in Cuddalore district. Multi-stage purposive sampling method was adopted for selection of the respondents. In this, contexts were selected from 3 select villages of Parangipettai block, Cuddalore district. Size of the primary inclusion is 120 . Hence the agricultural landless labourers play an important to role in agriculture sector where the production depends on both the agricultural landless labourers and landowning farmers.

Keywords: Landless Labourers, Problems, Wage, Employment
\end{abstract}

\section{INTRODUCTION}

India is the second the largest part populous country of the world and has changing socio-economic condition and political demographic and morbidity patterns that have been illustration global thought in current years. Agricultural landless labourers represent the largest part neglected class in Indian rural structure. Since they hold no skill or training, they have no alternative employment opportunities. One of the most characteristic features of the economy of India has been the increase in the number of agricultural landless labourers, cultivators engaged in crop production. The observable fact of underemployment, under-development and excess populace are at the same time clear in the daily lives and living of the agricultural landless labourers. They generally get low wages, environment of work put an excessive load on them, and the employment which they get is extremely irregular. Within society, a large number of agricultural landless labourers belong to scheduled castes and scheduled tribes. According to the National Commission on Labour, agricultural' labour consisted of two categories. They were (i) landless agricultural labourers and (ii) very small cultivators whose main source of earnings was through wage employment. As such, agricultural landless labourers yielded it into two broad categories: (a) permanent labour attached to a cultivating household and (b) casual labour. Casual labour is again subdivided into three groups namely (i) cultivators, (ii) share croppers and (iii) lease holders. Cultivators were those who possess very little land and devote most of their time working on the lands of others as labourers. Share croppers were those who share the produce of the land for their work and also work as labourers.

\section{REVIEW OF LITERATURE}

Aparna (2012) also showed the impact of MGNREGA on input use, labourers production, and in improving irrigation and infrastructural facilities and have therefore raise land rent. Card holders have used their money to introduce chemical fertilizers and machinery in their fields. From the above review, there is no particular study, which is based on agricultural work, wages and economic contributions of working to household income and pattern of expenditure and savings of agricultural labourers.

Radhakrishnaiah M. Sankaraiah (2015) examined that India is mainly an agrarian country where 70 percent of its populace still depends on agriculture for its livelihood. The agricultural labourers represent a great quantity of rural work force in India. In the present study males constitute 80.78 percent, nearly 38.19 percent of the agricultural labourers belong to Backward Caste, 66.89 percent of the agricultural labourers are illiterates, 78.24 percent live in nuclear families of agricultural labourers, 42.59 percent of agricultural labourers mixed type of houses., But 82.87 percent have own house around 34 per cent gave 2- 3 acres of land.

Subadevi M. Sunitha C. (2015) reviewed that economic growth is usually disturbed and clear to mean growth in per -capita gross domestic production produce by the labour force an economy. In that women labour represent an essential part. Hence women labour should be measured with an equal footing with men. Participation of women in economic activity in India is very general from time immemorial. The women are the backbone of agricultural workforce but universal her hard work has mostly been unpaid. She does the most tedious and back-breaking tasks in agricultural, animal husbandry and home. 
Raju B.V. (2017) examined that India is mainly an agrarian country. About 69 percent of its population still depends on agriculture for their living. The agricultural labourers constitute a considerable proportion of rural work force in India. In the present study area i.e., in Krishna District of Andhra Pradesh. Total population is 4517398 , out of these males constitute 2267375 and females constitute 2250023 . Nearly $44 \%$ of main workers in the district are agricultural labourers. Majority of the agricultural labourers are belongs to Scheduled Caste and Scheduled Tribes. Their income is low and unequal. Since they possess no skills or training and then have no different employment opportunity moreover. Therefore they are a suppressed class because of all these reasons their economic lot has failed to improve even after six decades of planning. Qualitative data were also collected through focus group discussion. Study shows that main cause of labour shortage is rural out-migration and MGNREGA work. The farmers are adopted various strategies to overcome labour shortage in agriculture such as use of family labour, increased use of machinery and hired labourers from outside the village. Farmers (especially small and medium farmers) unable to pay wage rate as equal to the MGNREGA wage rate due to low income from agriculture.

\section{STATEMENT OF THE PROBLEMS}

Since independence, India has been trying to reduce the level of unemployment rate in rural areas by initiating development measures and strategic options to eradicate poverty. The essential problems of the rural economy are low income, low productivity and be short of permanent employment. Though in recent times enacted MGNREGA, 2005 provides 100 days guarantee of employment in a year, there is great deal of fraud in issuing job cards. Moreover, gather rolls are not maintained accurately and work is not provided to job seekers who really are in need of such support. Every so often incidence is found in which fake names of workers are included and the work was being done with the help of machines which is cost effective. Use of JCB's, explosives, etc., in the place of man power was reported. Also for how many years surveillance should be taken under the said Act to provide employment is not clear. Planned effort to alleviate the agricultural labourers lot has failed because it consisted of temporary solutions disparate to the general pace and direction of economy as a whole. To succeed agricultural labourers policy has to be an important part of the overall policy of development. This programme for the longer term can then be supported by other shortterm programmes aimed at guarantee, in the intervening time, a more reasonable minimum wage to farm labourers, food and clothing at more practical prices through disciplined promotion the social order, and offseason employment opportunities for earning additional income.

The dimension of the problem of agricultural landless labourers disagree from region to region, depending on such factors as demands of population, availability of land for cultivation, differences in the extent of irrigation and double cropping, fertility of land, cropping patterns and opportunities available for seasonal migration and for employment outside agriculture. The considerable amount, the extensive underemployment that stay alive, and the fact there is enlarge in population has borne unkindly on this part of the labourers population. There is need for specific policies addressing the needs of part-time farm employments which will have a greater ability of success in providing boost for rural employment and economy. The problem of agricultural landless labourers is part of the wider problem of unemployment and under-employment in rural areas.

\section{OBJECTIVES OF THE STUDY}

1. To find out the socio economic conditions of the agricultural landless labourers in the study area.

2. To analyze the wage pattern of agricultural landless labourers.

3. To find out the main problems faced by agricultural landless labourers.

\section{METHODOLOGY}

The present study is based on primary data. In the study area, agricultural labourers are unemployed because they are low in wages due to lack of rain. Research is primarily a study of how the problems of agricultural workers face. The study is conducted among the farmers in the Parangipettai block in Cuddalore district. 120 respondents were interviewed using the questionnaire, and reviewed with secondary data collected from agricultural landless labourers and other sources of sample technology and primary data and agriculture with the help of observe methods.

\section{STUDY AREA}

This study has been conducted in three villages of Parangipettai block, which was selected in view of the availability of landless labourers involved in different occupations. Multi-stage purposive sampling method was adopted for selection of the respondents. Among the 3 villages of Parangipettai block, Cuddalore district was selected, since it has a different group of agricultural landless labourers engaged in various farming and nonfarming activities.

\section{SAMPLING TECHNIQUE}

Stratified random sampling techniques were followed. In this, contexts were selected from 3 select villages of Parangipettai block, Cuddalore district. Size of the primary inclusion is 120 .

\section{TOOLS AND DATA COLLECTION}

The Present study has conducted with help of wellstructured interview schedule for data collection. The 
interview schedules were distributed to Households and collected data are coded, edited, tabulated, and analyzed with SPSS computer package, suitable necessary 120 statistical tools, simple percentage, averages, chi square test used to analyze the economic condition, social and impacts of the livelihood status of the sample respondents in the study area.

TABLE I DISTRIBUTION OF THE RESPONDENTS BY THEIR SOCIO ECONOMIC STATUS

\begin{tabular}{|c|c|c|c|}
\hline Variable & Sub Group & Frequency & $\begin{array}{c}\text { Percentage } \\
(\%)\end{array}$ \\
\hline \multirow{5}{*}{ Age Group } & $18-30$ & 15 & 12.5 \\
\hline & $31-45$ & 23 & 19.2 \\
\hline & $46-60$ & 37 & 30.8 \\
\hline & 60 above & 45 & 37.5 \\
\hline & Total & 120 & 100 \\
\hline \multirow{3}{*}{ Gender } & Male & 84 & 70 \\
\hline & Female & 36 & 30 \\
\hline & Total & 120 & 100 \\
\hline \multirow{4}{*}{ Religion } & Hindu & 77 & 64.2 \\
\hline & Christian & 39 & 32.5 \\
\hline & Muslim & 4 & 3.3 \\
\hline & Total & 120 & 100 \\
\hline \multirow{5}{*}{ Community } & $\mathrm{MBC}$ & 15 & 12.5 \\
\hline & $\mathrm{SC}$ & 99 & 82.5 \\
\hline & ST & 6 & 5 \\
\hline & Others & - & - \\
\hline & Total & 120 & 100 \\
\hline \multirow{5}{*}{$\begin{array}{l}\text { Educational } \\
\text { Status }\end{array}$} & Primary & 51 & 42.5 \\
\hline & Secondary & 40 & 33.3 \\
\hline & Higher Secondary & 17 & 14.2 \\
\hline & Illiterate & 12 & 10 \\
\hline & Total & 120 & 100 \\
\hline \multirow{4}{*}{$\begin{array}{l}\text { Annual } \\
\text { Income }\end{array}$} & $48,000-56,000$ & 43 & 35.8 \\
\hline & $48,000-56,000$ & 48 & 40 \\
\hline & $48,000-56,000$ & 29 & 24.2 \\
\hline & Total & 120 & 100 \\
\hline \multirow{3}{*}{$\begin{array}{l}\text { Type of } \\
\text { Labour }\end{array}$} & Permanent Labour & 87 & 72.5 \\
\hline & Casual Labour & 33 & 27.5 \\
\hline & Total & 120 & 100 \\
\hline \multirow{3}{*}{$\begin{array}{l}\text { Type of } \\
\text { Family }\end{array}$} & Nuclear & 108 & 90 \\
\hline & Joint & 12 & 10 \\
\hline & Total & 120 & 100 \\
\hline \multirow{5}{*}{$\begin{array}{l}\text { Housing } \\
\text { Status }\end{array}$} & Hut & 07 & 5.8 \\
\hline & Thatched & 41 & 34.2 \\
\hline & Katcha & 26 & 21.6 \\
\hline & Concrete & 46 & 38.4 \\
\hline & Total & 120 & 100 \\
\hline
\end{tabular}

\section{A. Primary Data}

Primary data is the main source of information in this study. The present study based mainly on primary data which is collected with the help of structured interview schedules in the Parangipettai block.

\section{B. Secondary Data}

Secondary source of data is also collected for this study. The study also carried on depending secondary source of data, which are collected from the government offices in Cuddalore district of Tamil Nadu, as well as from the Village Panchayat, of the study area. Some Governmental, Non-governmental sectors and international publications and reports related to study area, are also included, as the source of secondary data.

Socio Economic Status:

From the survey, the table I inferred that the majority $(37.5 \%)$ of the landless labourers belonging to the age group of above 60 years. Regarding gender is the great strength $(70 \%)$ of the respondents. Based on the religion, nearly $(64.2 \%)$ of the landless labourers. The community based $(82.5 \%)$ of the landless labourers belong to schedule caste in the study area. Regarding educational status, the great strength $(42.5 \%)$ of the respondents has studies up to schooling earthier primary level only. In terms of annual income, the majority (35.8\%) of the respondents are able to earn Rs. 48,000-56,000 per annual income as their source of livelihood. Regarding labour type is the great strength (72.5\%) of the permanent labour. Most respondents are $(90 \%)$ of nuclear family and also (38.4\%) of the respondents live in own concrete houses in the study area. Besides, all the respondents they get their wage in daily respectively. Moreover, it is heartening to note that the majority of the agricultural facilities in their houses such as safe drinking water, toilet facility, drinking facility are not respectively. Further, some respondents are using firewood as fuel for cooking in their houses.

TABLE II DisTRIBUTION OF THE RESPONDENTS BY THEIR DAILY WAge PATTERn OF AgRicultuRAL LANDLESS LABOURERS

\begin{tabular}{|l|c|c|}
\hline $\begin{array}{c}\text { Daily Wages of } \\
\text { Agricultural } \\
\text { Landless Labourers }\end{array}$ & Frequency & Percentage \\
\hline Rs. 150-200 & 54 & 45 \\
\hline Rs. 250-350 & 66 & 55 \\
\hline Total & 120 & 100 \\
\hline
\end{tabular}

From the data in the table II that the majority of the respondents $(55 \%)$ get the daily wages in between Rs. 250350 , followed by only $(45 \%)$ respondents get the daily wages of the Rs.150-200. The data regarding the daily wages the male agricultural labourers receive shows that a majority $(55 \%)$ of the respondents receive more than 250 350 rupees as their wages. Because, their post life period continues to follow. 
TABLE III Distribution Of THE RESPONDENTs By THEIR PROBLEM THAT COME From THE MACHINES

\begin{tabular}{|l|c|c|}
\hline \multicolumn{1}{|c|}{ Variables } & Frequency & Percentage \% \\
\hline Unemployment & 60 & 50 \\
\hline Wage problem & 42 & 35 \\
\hline Problem with landlords & 18 & 15 \\
\hline Total & 120 & 100 \\
\hline
\end{tabular}

From the survey, the table III inferred that the majority of the respondents are problem that come from the machines such as unemployment is the mainly focused on percentage of $(50 \%)$. Further, is heartening to note that the significant strength of the agricultural landless labourers is problem with the machines.

TABLE IV DistribUtion OF THE RESPONDENTS By THEIR PROBLEMS FACED BY AGRICULTURAL LANDLESS LABOURERS

\begin{tabular}{|l|c|c|}
\hline \multicolumn{1}{|c|}{ Variables } & Frequency & $\begin{array}{c}\text { Percentage } \\
(\%)\end{array}$ \\
\hline $\begin{array}{l}\text { Unemployment during off } \\
\text { season }\end{array}$ & 26 & 21.7 \\
\hline $\begin{array}{l}\text { Less opportunity sources of } \\
\text { employment }\end{array}$ & 12 & 10 \\
\hline Poverty / Debt & 16 & 13.3 \\
\hline $\begin{array}{l}\text { Non -availability of } \\
\text { MGNREGS Jobs }\end{array}$ & 19 & 15.8 \\
\hline $\begin{array}{l}\text { Discrimination in Wages / } \\
\text { Low Wages }\end{array}$ & 9 & 7.5 \\
\hline $\begin{array}{l}\text { Men were doing physically } \\
\text { hard type work }\end{array}$ & 11 & 9.2 \\
\hline Health weakness of women & 7 & 5.8 \\
\hline $\begin{array}{l}\text { Unable to do the jobs like } \\
\text { the use of farm machinery }\end{array}$ & 20 & 16.7 \\
\hline Total & 120 & 100 \\
\hline
\end{tabular}

Based on the field investigation, the table IV expressed that the problems faced by agricultural landless labourers wise distribution of the respondents out of the total 120 respondents in each category, it is observed that problems faced by agricultural landless labourers the majority of respondents is faced by problem unemployment during off season $(21.7 \%)$. Followed by unable to do the jobs like the use of farm machinery (16.7\%). Further, it is sadly to note in the main problem of the unemployment during off season that the majority of agricultural landless labourers.

\section{FINDINGS OF THE STUDY}

This study is a component for effort the full issue of agricultural landless labourers was done primarily based on primary data. The study analyses the employment and income generation of agricultural landless labourers and extend of indebtedness and earning of wage pattern prevalent the agricultural households in Parangipettai block with a view to understanding their agricultural landless labourers problems. The increasing agricultural landless labourers problem due to high level of machines and decreasing agricultural land. The land concentrated few big farmers and landless agricultural labourers are unorganized illiteracy poverty absence of alternative occupation and seasonal unemployment is found in the study area. So there creates agricultural landless labourers problems in the study area.

\section{CONCLUSION}

In this study conclude that the problems faced by agricultural landless labourers is not so good in, their living standard and income is very low. The wages are found to be varying on the gender basis and the kind of work they perform. To improve the agricultural landless labourers working condition, to improve the development of rural areas like better irrigation faculties, water, employment, sanitation, housing and road facilities etc. To improve the conditions, government should take proper steps for various aspect for agricultural landless labourers, like wage pattern, hours of works, improve the living conditions and overcoming the natural factors like flood, draughts and erosion etc. Agricultural landless labourers status is low by all social economic conditions. The skilled landless labourers from other districts found working in farm works as drivers and harvester operators. Hence the agricultural landless labourers play an important to role in agriculture sector where the production depends on both the agricultural landless labourers and landowning farmers.

\section{REFERENCES}

[1] Aparna, (2012). Shortage of agricultural labour due to MGNREGS-A hoax, Voice of Resistance, 1(2), 3-7.

[2] Bardhan \& Kalpana, (1973). Factors Affecting Wage rates for Agricultural Labour. Economic and Political Weekly, 8(26), 56 - 64.

[3] Chhina, S. S. (2009). Women Labour Problem and Policy Implications. New Delhi: Regal Publications.

[4] Dineshkumar, S.D. (2017). Socio-Economic Conditions of Women Agricultural Labourers in Cuddalore District. International Journal of Humanities \& Social Science Studies (IJHSSS).

[5] Anupama Rajput, "Agriculture Labour in India", Economic development and policy of India.

[6] Kaleeshwaran, M., \& Rajalakshmi, C. (2015). Contribution of female labour in agriculture: A case study of Erode district of Tamil Nadu. International journal of Scientific and Research Publications, 5(2).

[7] Radhakrishnaiah, M \& Sankaraiah, (2015, June). Socioeconomic Conditions of Agricultural Labour in Rayalaseema, Andhra Pradesh, 4.

[8] Subadevi, M. \& Sunitha, C. (2015). A study on socio economic conditions of landless agricultural females labourers in Thanjavur, EPRA International Journal of Economic and Business Review, 3.

[9] Sangita, \& Dumore, V. (2016). Economic Study of Landless Labourers' Problems in Maharashtra, International Journal of Advance Research in Science and Engineering, 5.

[10] Raju, B.V. (2017). Agriculture Labour's Socio-Economic Conditions A Study In Krishna Dist., Andhra Pradesh, IOSR Journal of Business and Management (IOSR-JBM), 19. 